\title{
Transformations and Convergences: The Evil Eye in Melville's Fiction
}

\author{
By James Kirkland ${ }^{*}$
}

\begin{abstract}
Based on the assumption that certain people and animals can kill or injure with a glance, the evil eye- also known as "eye bite," "angry eye," overlooking," "fascination," "invidia," and other names -is, in the words of folklorist Alan Dundes, "not some old fashioned superstitious belief of interest solely to antiquarians" (1992: viii-ix) but a multi-faceted "folk belief complex" of "great antiquity" and vast geographical distribution (1992: vii). It also plays a prominent role in the fiction of Herman Melville, appearing as a major folkloric subtext in three of the four novels published between 1847 and 1851-one of the most productive periods in Melville's literary career -as well as in his final novel Billy Budd, which he was still working on at the time of his death in 1891. As this study demonstrates, these works offer a rare glimpse into the evolution of a complex folkloric phenomenon in literary contexts as varied as the social and cultural settings in which it is traditionally situated.
\end{abstract}

Keywords: Melville, evil eye, fascination, folklore, superstition.

\section{Introduction}

Although Melville's fascination with the supernatural has been noted by numerous biographers and critics, little attention has been paid to one of the most pervasive and significant supernatural traditions in his fiction: the cluster of beliefs, rituals, and events known collectively as the evil eye. Kevin Hayes, for example, makes no mention of the evil eye in Melville's Folk Roots (1999), and the one study that does address the subject -Joseph Adamson's Melville, Shame, and the Evil Eye (1997)-eschews folkloristic analysis in favor of a psychoanalytic interpretation grounded in the work of shame theorists such as Heinz Kohut, Silvan Tomkins, and Leon Wurmser. By contrast, I argue in this article that while psychoanalytic and folkloristic approaches are by no means mutually exclusive, the evil eye is first and foremost a folkloric phenomenon that Melville continually adapted to new fictional situations and purposes, following a process that contemporary folklore/literature scholars Frank de Caro and Rosan Jordan describe as "the process by which folklore is somehow taken from its position in a sociocultural context (de-situation) and placed into a literary or artistic context, whether by description, textual quotation, or some other means (such as the adaptation of a plot structure) (re-situation)" (2004: 6). Among the questions that are most central to such an inquiry are the following: What are the key genric and performance features of the evil eye in folk cultural context? What biographical, textual, or other evidence is there to corroborate Melville's familiarity with this body of traditions? Which specific aspects of evil eye folklore find expression in Melville's fiction, and what meanings are generated by this border-crossing

*Professor of English, East Carolina University, USA. 
process in Mardi, Redburn, Moby Dick, and Billy Budd - the four novels in which the belief complex plays a central role?

\section{The Evil Eye in Historical Perspective}

Anyone researching the evil eye would do well to begin with Arnold van Gennep's story "The Research Topic: Or, Folklore without End," which recounts the experiences of a young scholar who began doing research on the evil eye at the age of 18 and became so immersed in his work that he was still accumulating data at the age of 54, by which time he had learned hundreds of languages, compiled 27,000 bibliography items, and written 12,000,000 notes (Van Gennep 1992: 7). Unfortunately for the scholar, he died at his carrell while updating his bibliographywithout having published a single item. The story, of course, is apocryphal and the tone decidedly humorous, but the scholar's predicament is all too real.

Based on the assumption that certain people and animals "possess eyes whose glance has the power to injure or even kill" (Jones 1951: 11), the evil eye -also known as "eye bite," "angry eye," overlooking," "fascination," "invidia," and other names- is, in the words of folklorist Alan Dundes, "not some old fashioned superstitious belief of interest solely to antiquarians" (1992: viii-ix) but a multifaceted "folk belief complex" of "great antiquity" and vast geographical distribution (1992: vii). References to it appear in ancient "Assyrian and Akadian documents" as well as "in the Bible,...in the Apocrypha, in the Talmudic writings,...in the Koran," and a host of other religious writings from "Old Testament times" (Hand 1980: 240). Plato mentions it, as do Aristotle, Plinny, Plutarch, Ovid, Herodotus, and other classical authorities (Kirkland 1999: 136). Bacon devotes a chapter to the subject in his Essays and Counsels Civil and Moral. Shakespeare alludes to it in the Merchant of Venice. Lewis's Monk, Beckford's Vathek, Mary Shelley's Dimitri of the Evil Eye, and numerous other Gothic villains possess the power, as do the supernatural enchantresses of "Christabel," "La Belle Dam San Merci," and other poems of the English Romantics. And numerous other examples can be found in nineteenth century American fiction, including Edgar Allan Poe's "The 'Tell-Tale' Heart" and Nathaniel Hawthorne's The House of the Seven Gables.

\section{Melville and the Evil Eye}

Melville's familiarity with these works and authors has been thoroughly documented in such standard references as Nathalia Wright's Melville's Use of the Bible (1949), Merton Sealts's Melville's Reading: Revised and Enlarged Edition (1998), and Mary Bercaw's Melville's Sources (1988). Thus, it seems logical to assume that at least some of the beliefs and practices associated with the evil eye he learned indirectly through printed sources. However, as Kevin Hayes observes in the preface to Melville's Folk Roots, what Melville "heard from his friends, family members, ship mates, and fellow patrons of the barber shop and the tavern" 
was as important to him as a writer as what he "might have read" (Hayes 1999: x), and his fictional depictions of the psycho-social dynamics of the belief complex correspond so closely to the realities of the folk event documented by ethnographers that Melville was almost certainly guided as well by insights gleaned from direct participation in folk tradition.

\section{From Mardi to Billy Budd: The Literary Evolution of the Evil Eye Belief Complex}

In Mardi, the third of Melville's novels and the first to mention the evil eye, the person endowed with this attribute is the enigmatic Hautia, an otherworldly being who has as much in common with Coleridge's Geraldine or Keat's Lamia as with the "fascinator" or "overlooker" of folk tradition. First introduced in ch. 61 just after the narrator has assumed the name of the Demi-God Taji to enhance his stature among the Mardian islanders, Hautia is, from the outset, "a mysterious figure" with a "solitary eye" (Melville 1970: 186) which produces an effect on Taji and his companion Yillah that is consistent with both folkloric and literary perceptions of the individual possessed of the evil eye:

"Now it [the eye of the stranger] was fixed upon Yillah with a sinister glance, and now upon me, but with a different expression. However great the crowd, however tumultuous, that fathomless eye gazed on; till at last it seemed no eye, but ever a spirit, forever prying into my soul" (Melville 1970: 186).

Later, when Taji and his companions approach the Isle of Flozella in search of Yillah, who has mysteriously vanished from the island of Odo, they encounter Queen Hautia, whose kinship with the mysterious stranger becomes immediately apparent. Her eye, Taji observes, is "fathomless"-a "mysterious, evil-boding gaze" (Melville 1970: 646) to which he soon gives a name: "Is not that, the evil eye that long ago did haunt me" (Melville 1970: 640)? Because Hautia is described variously as a "phantom," an "enchantress," and a "syren," Stith Thompson's Motif A 128.2.1-"God with the Evil Eye"- seems an especially apt descriptor, as does Motif D 2072.1, "Magic Paralysis" (Thompson 1966), which is applicable both to Hautia's maidens, whom the historian Mohi believes to be "all Yillahs, held captive, unknown to themselves" (648), and to Taji, who believes himself to be under a "spell" so powerful that Hautia...through her fixed eyes, slowly drank up my soul" (Melville 1970: 652).

By evoking these popular associations of the supernatural (Di Stasi 1981: 23), Melville draws attention not only to Hautia's allegorical role as carnal goddess tempting the hero to abandon his spiritual quest, symbolized by Yillah, but also to the ambiguities inherent in the quest itself- a quest for truth compromised from the outset by murder and deceit.

In Redburn, Melville's next novel, the scene shifts from the enchanted isles and grottoes of Mardi to the shipboard world of the Highlander, where the fascinator is not a lamia or some other supernatural being but an ordinary sailor by 
the name of Jackson, and his victims are not phantom maidens or demigods but his own shipmates.

These changes in no way diminish, however, the impact of the evil eye on the lives of the characters or the consciousness of readers conversant with the particulars of the belief complex. In fact, they bring the fictional situation much closer to the folk event than was possible in the previous book.

Especially striking are the similarities between the overlooker of folk tradition and the evil-eyed Jackson. According to ophthamologist Edward Gifford, "In general any condition of the eyes which apppears to be abnormal or unusual may awaken the fear of the fascinator" (Gifford 1958: 21) and particularly suspect are those with "prominent, brilliant, or glittering eyes" (Gifford 1958: 22) or "anyone whose eyes differ in color from those of his neighbors" (Gifford 1958: 22). Also susceptible to evil eye accusation are those who are cross-eyed (Meerloo 1971: 33) or "blind in one eye" (Brav 1992: 49), and those whose eyebrows meet, "forming two prominent semicircular arcs above the eyes, which enlarge their concentric contours" (Coss 1974: 22).

Jackson, to whom Redburn explicitly attributes the evil eye when he says, "I could not avoid Jackson's evil eye, nor escape his bitter enmity" (Melville 1969: 62 ), fits the profile of the overlooker in virtually every detail. "Did you ever see a man," Redburn asks, "with his hair shaved off, and just recovered from the yellow fever? Well, just such a looking man was this sailor" (Melville 1969: 56)-a man whom Redburn later characterizes as "such a hideous looking mortal, that Satan himself would have run from him" (Melville 1969: 57). Though Jackson has two eyes, he "squinted with one eye, and did not look very straight out of the other" (Melville 1969: 56)-peculiarities that take on more ominous associations in Redburn's later comment that "One glance of his squinting eye, was as good as a knock-down, for it was the most deep, subtle, infernal looking eye, that I ever saw lodged in a human head" (Melville 1969: 57). This glance is not only intense and piercing but suggestive of the paralyzing gaze of reputed animal and reptilian fascinators: "I believe, that by good rights it must have belonged to a wolf, or starved tiger; at any rate, I would defy any oculist, to turn out a glass eye, half so cold, and snaky, and deadly" (Melville 1969: 57).

As these details suggest, the evil eye is a powerful agency and its possessor is someone to be feared. "All the men were afraid of him, and durst not contradict him, or cross his path in anything" (Melville 1969: 57). Redburn reports "They all stood in mortal fear of him; and cringed and fawned about him like so many spaniels" (Melville 1969: 59). As for himself, Redburn invariably shuddered when "I caught this man gazing at me, as I often did," with "his eyes fixed, and his teeth set, like a man in the moody madness" (Melville 1969: 58).

Not content merely to record the effects of Jackson's gaze on himself and other members of the crew, Redburn seeks answers to a more fundamental question: what motivates Jackson to act as he does? For many participants in the folk belief complex, the evil eye is synonymous with envy. In fact, Joost Meerloo calls the evil eye "the gaze of envy" (1971: 31), reaffirming $19^{\text {th }}$ century evil eye scholar Frederic Elworthy's thesis that "invidia, envy, or evil eye" is "the instigator of most deadly sins-the vice which is even now most frequently named in 
connection with...'hatred, and malice, and all uncharitableness'" (1895, 1958: 7). Similarly, psychoanalytic critic Richard Adamson characterizes the evil eye as "that malignant looking...that 'invidiously' compares to the self everything it happens to light on" (1997: 148).

Redburn articulates much the same philosophy when attempting to explain Jackson's antipathy for him:

"I was young and handsome, at least my mother so thought me, and as soon as I became a little used to the sea, and shook off my low spirits somewhat, I began to have my old color in my cheeks, and, spite of misfortune, to appear well and hearty; whereas he was being consumed by an incurable malady, that was eating up his vitals, and was more fit for a hospital than a ship" (Melville 1969: 58).

The connection between envy and the evil eye also helps to explain why "the weaker and weaker he grew, the more outrageous became his treatment of the crew" (Melville 1969: 276).

More difficult to explain is the compassion Redburn feels for his tormentor. "Though there were moments when I almost hated this Jackson," Redburn admits, "yet I have pitied no man as I have pitied him" (Melville 1969: 105). Why? Because "there seemed even more woe than wickedness about the man; and his wickedness seemed to spring from his woe; and for all his hideousness, there was that in his eye at times, that was ineffably pitiable and touching" (Melville 1969: 105). If Jackson had indeed sold his soul to the Devil as Redburn implies elsewhere, then there would be no reason for compassion or empathy. But if he has what is known as the "involuntary" evil eye, he has no control over the power or the damage it may cause the objects of his gaze; thus, in the words of Howard Stein "Compassion is due not only the one stricken by the evil eye, but equally the unfortunate" who casts it (Stein 1976: 209) -a conclusion supported also by Thomas Davidson, who terms the involuntary evil eye "a curse to the unhappy possessor" (Davidson 1992: 145).

Though not mentioned in Melville's next book, White Jacket, the evil eye reappears in his sixth novel Moby Dick in Father Mapple's retelling of the biblical story of Jonah, where it takes on a very different form than in previous novels. Jonah embarks, Mapple reminds his congregation, from "Joppa, the modern Jaffa...on the most easterly coast of the Mediterranean" (Melville 1988: 43) where the evil eye belief complex is perhaps stronger than anywhere else in the world. And the minister's description of Jonah's appearance and behavior, an imaginative elaboration of the biblical text rather than a literal transcription, seems calculated to arouse in his auditors exactly the kinds of suspicions that might be anticipated in a folk cultural context. Jonah has what Mapple describes as a "guilty eye"-a "disordered, self-condemning-look" (Melville 1988: 43) that sets him apart from others and makes him an outcast even on a crowded wharf or ship. As he proceeds, Mapple continues to alter the biblical text, eventually making explicit the reason for Jonah's alienation: "all the sailors for the moment desist from hoisting in the goods, to mark the stranger's evil eye" (Melville 1988: 43).

Although the Book of Jonah makes no mention of the evil eye, Mapple clearly assumes that his auditors will understand its appropropriateness to Jonah 
because the focus of the sermon shifts immediately to the interaction between the individual accused of having the evil eye and other members of the community. Although Mapple says nothing to suggest that Jonah actually casts the evil eye on someone else -as Hautia does to Taji or Jackson to Redburn- he is nonetheless held responsible for the storm that threatens the life of everyone on board the ship. According to Tobin Siebers, this is the common fate of the person reputed to have the evil eye: to "become isolated at the heart of the community" and to serve as a "living victim who elicits and polarizes the desires of his neighbors" (1983: 56).

Another link between Mapple's narrative and folk tradition is the sympathy accorded the individual presumed to have the evil eye. Just as Redburn pities Jackson, the sailors- though "appalled" by Jonah's confession of his disobedience to God-"still are pitiful" (Melville 1988: 46), perhaps because in Father Mapple's version of the story, they recognize that they, too, are "all sinners among men" (Melville 1988: 42).

Ultimately, however, the most significant of Mapple's emendations to the biblical text is the one he does not make. In the sermon, as in the biblical narrative, Jonah is redeemed through repentance and obedience -presumably casting aside his evil eye in the process. But in a social context, the individual accused of overlooking is powerless to change; thus the evil eye becomes a lifelong curse regardless of the individual's moral character or religious convictions.

Thus, in the very act of eliciting from his auditors their "strong intuitions" (Melville 1988: 43) of the evil eye belief complex that support his interpretation of the scriptural text, Mapple invites potentially conflicting responses, just as Ishmael does by reporting without comment the minister's words. The result is the same kind of ambiguous relativism that underlies almost every utterance and event in the novel and undermines any attempt to discover ultimate truth whether it is embodied in Mapple's allegory of sinful humanity reunited with God through repentance or in the whiteness of the whale.

By the end of the decade, Melville had abandoned his pursuit of a literary career, but his interest in the evil eye never waned, for he returned to it with an even deeper understanding of its social, psychological, and metaphysical dimensions in his final novel Billy Budd, Sailor (An inside Narrative). Composed during the last four years of his life and published posthumously in 1924, Billy Budd tells a story very similar to the one he had recounted more than forty years before in Redburn. Once again, a young man, innocent in the ways of the world, unknowingly incurs the enmity of another member of the ship's company- a man with a mesmeric eye and an evil nature that defy rational explanation. But this time, the setting is a British man of war on patrol in the Mediterranean at the heigth of the war between England and France, not an American merchant vessel plying the waters between New York and Liverpool on a routine peacetime voyage. The possessor of the evil eye is a man with real power over the men below his rank and the capacity to use it, rather than an ordinary seaman who does nothing more than verbally abuse and threaten his peers. The victim of the overlooker is even more innocent than the protagonist of the earlier novel but without the intelligence to recognize and avoid the evil that confronts him. And the 
outcome of the encounter between these two men has tragic consequences only hinted at in the earlier work.

The last and most complex of Melville's evil-eyed characters is John Claggart, the master-at-arms of the HMS Bellipotent. Though, less repugnant physically than Jackson, Claggart has the distinctive facial and ocular traits of the folk fascinator; his "eye could cast a tutoring glance" (Melville 1962: 64). His "brow was of the sort phrenologically associated with more than average intellect," but his pallid "complexion, singularly contrasting with red or deeply bronzed visages of the sailors, seemed to hint of something defective or abnormal in the constitution and blood" (Melville 1962: 64). The "glance" he directs at Billy from afar is described as "an immitigable look, pinching and shrivelling the visage into the momentary semblance of a wrinkled walnut" (Melville 1962: 88) -a look that intensifies "upon any abrupt unforseen encounter" (Melville 1962: 88) with the young foretopman. At those moments, "a red light would flash forth from his eye like a spark from an anvil in a dusky smithy", a "quick, fierce light" that "darted from orbs which in repose were of a color nearest approaching a deeper violet, the softest of shades" (Melville 1962: 88).

Claggart's physical characteristics alone would make him susceptible to evil eye accusations in almost any of the societies in which the folk belief complex exists, but there are others of equal importance, notably the overt expressions of admiration and praise for Billy that belie his true feelings of hate and envy.

Especially significant in this regard is Claggart's response to Billy when the foretopman "chanced in a sudden lurch" of the ship "to spill the entire contents of his soup pan upon the new-scrubbed deck" (Melville 1962: 72) just as the masterat-arms was passing by: "'Handsomely done, my lad! And handsome is as handsome did it, too' (Melville 1962: 72)! Here, Billy takes Claggart's words at face value, as he does earlier when told by his shipmates that the master-at-arms calls him 'the sweet and pleasant young fellow' (Melville 1962: 71), but he does not see the 'involuntary smile, or rather grimace, that accompanied Claggart's equivocal words' (Melville 1962: 72) and cannot comprehend why the old Dasker continues to insist that Jemmy Legs' (meaning the master-at-arms) 'is down on you'" (Melville 1962: 71).

Readers familiar with the evil eye complex would have no such difficulties, however. Brian Spooner speaks to the issues raised in the fictional situation from an anthropological perspective, noting that "any form of admiration is feared as a potential vehicle for the evil eye" (Spooner 1976: 80) -a point reaffirmed by Regina Dionisopoulos-Mass (1976), who argues that "The first dynamic of power is that of the evil eye. This is a power of the eye (an admiring look), the thought, or a voiced compliment...the compliment is a threat, one expressing the envy of the complimenter for the admired one's good fortune. It is a threat covered with words of flattery and praise" (Dionisopoulos-Mass 1976: 44-45).

Although Billy has a "good nature, indicating no mental superiority tending to excite an invidious feeling" (Melville 1962: 89), the moment he is impressed into service on the Bellipotent, he unknowlingly provokes such feelings in Claggart. At first it appears that "what it was that had first moved him against Billy" was simpy the latter's great "personal beauty" (Melville 1962: 77), but as we soon learn, 
Claggart's envy "was no vulgar form of the passion. Nor, as directed toward Billy Budd, did it partake of that streak of apprehensive jealousy that marred Saul's visage perturbedly brooding on the comely young David" (Melville 1962: 78). Rather, "Claggart's envy struck deeper. If askance he eyed the good looks, cheery health, and frank enjoyment of young life in Billy Budd, it was because these went along with a nature that, as Claggart magnetically felt, had in its simplicity never willed malice or experienced the reactionary bite of that serpent" (Melville 1962: 78).

Here, and elsewhere in the eleven chapters that make up what Hayford and Sealts term the "second phase in Melville's development of the novel," in which "Claggart was either introduced or brought to the fore as the cause of Billy's predicament" (Melville 1962: 5), Melville delves much more deeply into the psychological and intellectual dimensions of the belief complex than he had in his earlier novels, anticipating by more than a century the discoveries of contemporary envy/jealousy theorists such as Mervyn Nicholson:

"Envy is close to jealousy-the feeling of anger and hostility toward someone of preferred status or quality, but it is also close to malice-an unmotivated hatred that seeks to damage another person, and that enjoys the suffering of others: a hatred of what is good because it is good. Thus, unavoidably, envy takes us deeply into the mystery of evil, in a way that few topics can" (1999: 2).

Although Nicholson makes no mention of Melville or Billy Budd, he addresses here one of the novel's central concerns, the "mystery of evil" or as the narrator puts it the "mania of an evil nature, not engendered by vicious training or corrupting books or licentious living, but born with him and innate, in short, 'a depravity according to nature"' (Melville 1962: 76).

Through the nine chapters leading up to the climactic accusation and confrontation scenes (chapters 18 and 19), Claggart has been careful to conceal from public view his iniquitous and invidious nature and to avoid what Louis Jones refers to in another context as "the direct, long-held, piercing stare" that "people fear and recognize as the [mark of] one who carries malevolent power" (1951: 15). But by the end of Ch. 17, the "monomania in the man -if that indeed it were- ...like a subterranean fire, was eating its way deeper and deeper in him." And so "Something decisive must come of it" (Melville 1962: 90).

The first of those decisive actions, recounted in ch. 18, where Claggart seeks an audience with Captain Vere on the quarter deck to accuse Billy of mutiny, sets the stage for the far more decisive events that take place in Vere's cabin in Ch. 19, where the diverse elements of the evil eye belief complex converge. Once again, an understanding of the folk belief complex helps illuminate the fictional situation. As Sam Migliore reminds us in Mal'uocchiu: Ambiguity, Evil Eye, and the Language of Distress, mal'uocchiu (the evil eye) in the folk cultural context "involves primarily two components; 1) a gazer,... who possesses the power to cause harm by directing a glance....at another individual in anger, envy..., or simply overadmiration; and 2) the victims...(the stricken)-anyone exposed to and affected by mal'uocchiu" (1997: 34)-both of whom are negatively impacted by this interpersonal encounter. The gazer, Migliori argues, "is capable of injuring 
others because he or she is in a highly emotional state, and because emotions such as envy (mimidia) activate and increase an individual's strength to the point at which mal uocchiu becomes effective" (1997: 35). Yet envy is such a powerful emotion it "can also turn inward," creating a state of disequilibrium as profound as that experienced by victims of the evil eye, who "are susceptible to mal'uocchiu because their strength/weakness balance has been disrupted by a physical disability, previous exposure to the phenomenon, or other factors" (Migliore 1997: 34 ), often resulting in "mental disorders; partial or total paralysis; and, in rare cases, death" (1997: 36).

The climactic confrontation between Claggart and Billy follows closely the "process of social interaction" (Migliore 1997: 360) outlined by Migliori and numerous other ethnographers (see in particular Garrison and Arensberg 1976, Hand 1980, Siebers 1983), beginning with a direct ocular attack by Claggart (the gazer) and its effect on the Billy (the gazee), who is unable to move or speak: "Claggart deliberately advanced within short distance of Billy and, mesmerically looking him in the eye, recapitulated the accusation [of mutiny]. ... Not at first did Billy take it in. When he did, the rose-tan of his cheek looked struck as if by white leprosy. He stood like one impaled and gagged" (Melville 1962: 98).

Emboldened by Billy's inability to respond, Claggart continues his assault, the effects of which are magnified by dramatic changes in the color and size of his eyes:

\begin{abstract}
"Meanwhile, the accuser's eyes, removing not as yet from the blue dilated ones, underwent a phenomenal change, their wonted rich violet color blurring into a muddy purple. Those lights of human intelligence, losing human expression, were gelidly protruding like the alien eyes of certain uncatalogued creatures of the deep. The first mesmeristic glance was one of serpent fascination; the last was as the paralyzing lurch of the torpedo fish (Melville 1962: 98).
\end{abstract}

Given the potency of Claggart's gaze and its association with both mesmerism which according to Elworthy was for centuries synonymous with the word "fascination" (Elworthy 1895, 1958: 7)- and two of the most feared animal fascinators the serpent and the torpedo fish (see in particular Siebers 1983: 62), it is not surprising that "such an accusation so suddenly sprung on inexperienced nonage" coupled with "the horror of the accuser's eyes" would first "bring out his lurking defect" (Melville 1962: 98) and ultimately end in "confirming the paralysis" (Melville 1962: 99).

What is surprising, from a folkloristic perspective, is the suddeness with which Billy's paralysis (a common symptom of overlooking) is transformed into physical violence (an uncommon occurrence in most folk communities, where amuletic magic and community support offer alternative ways of annuling or deflecting the evil eye): "quick as the flame from a discharged cannon at night," Billy's "arm shot out, and Claggart dropped to the deck" (Melville 1962: 99). While it is possible that in this instance Melville had in mind an atypical version of the evil eye event, such as the Scottish tradition of "scoring aboon the breath," in which the victim of the evil eye or someone acting on the victim's behalf physically attacks the suspected fascinator, "drawing a blunt instrument across the 
forehead to the effusion of blood" (Davidson 1992: 147), it seems more likely that he was simply following his long-standing practice of combining details culled from his sources, both oral and written, with his own imaginative inventions-a process much like that described by Frank de Caro and Rosan Jordan in ReSituating Folklore: Folk Contexts in Twentieth-Century Literature and Art: "As in social interaction, folklore in literature may...find its meanings from the contexts where it appears -in the life world of the fictional narrative as in the original context from which it has been de-situated. Meaning is multivalent and the very process of de- and re-situation involves many choices and complexities" (de Caro and Jordan 2004: 267).

\section{Conclusion}

In the man-of-war world of Billy Budd, where violence is the norm, the cannon-like discharge of Billy's arm is as natural as the typically non-violent means of combattiing the evil eye in the folk context. Moreover, the confrontation scene as a whole constitiutes one of the most sustained and ethnographically accurate accounts of the evil eye event in American literature and also serves as the final act of the folk drama rehearsed decades earlier in Mardi, Redburn, and Moby Dick.

Taken together, these four works, spanning over four decades of Melville's life, offer a rare glimpse of the evolution of a complex folkloric phenomenon in literary contexts as varied as the social and cultural settings in which it is traditionally situated, revealing in their own unique ways Melville's intuitive awareness of principles articulated over a hundred years later by cultural anthropolist Sam Migliore: "The evil eye," he argues, "is not something specific and absolute; it is an ambiguous cultural construct whose meaning varies crossculturally, and that is open to interpretation, argument, and negotiation within specific sociocultural [and literary] contexts" (Migliore 1997: 12). Of all this, and more, Ishmael might have said, the evil eye is a symbol.

\section{References}

Adamson J (1997) Melville, shame, and the evil eye: A psychoanalytic reading. Albany: State University of New York Press.

Bercaw M (1987) Melville's sources. Evanston: Northwestern University Press.

Brav A (1992) The evil eye among the Hebrews. In The Evil Eye: A Casebook, A Dundes (ed), 44-54. Madison: University of Wisconsin Press.

Coss R (1974) Reflections on the evil eye. Human Behavior 3(10): 16-22.

Davidson T (1992) Scoring aboon the breath: defeating the evil eye. In The Evil Eye: A Casebook, A Dundes (ed), 143-149. Madison: University of Wisconsin Press.

De Caro F, Jordan R (2004) Re-Situating folklore: folk contexts and twentieth-Century literature and art. Knoxville: University of Tennessee Press.

Dionisopoulos-Mass R (1976) The evil eye and bewitchment in a peasant village. In The Evil Eye, C Maloney (ed), 42-62. New York: Columbia University Press. 
Di Stasi L (1981) Mal occhio: The underside of vision. San Francisco: North Point.

Dundes A (1992) Preface. In The Evil Eye: A Casebook, A Dundes (ed), vii-ix. Madison: University of Wisconsin Press.

Elworthy F (1958) The evil eye: the origins and practices of superstition (1895). New York: Julian.

Garrison V, Arensberg C (1976) The evil eye: envy or risk of seizure? paranoia or patronal dependency? In The Evil Eye, C Maloney (ed), 286-328. New York: Columbia University Press.

Gifford E (1958) The evil eye: studies in the folklore of vision. New York: MacMillan.

Hand W (1980) The evil eye in its folk medical aspects: a survey of North America. In Magical Medicine, W Hand (ed), 239-249. Berkeley: University of California Press.

Hayes K (1999) Melville's folk roots. Kent: Kent State University Press.

Jones L (1951) The evil eye among European-Americans. Western Folklore 10(1): 11-25.

Kirkland J (1999) The "Tell-Tale Heart" as evil eye event. Southern Folklore 56(2): 135147.

Meerloo J (1971) Intuition and the evil eye: the natural history of a superstition. Wassenar, The Netherlands: Servire.

Melville H (1962) Billy Budd Sailor: an inside narrative (1924). H Hayford, M Sealts (eds). Chicago: University of Chicago Press.

Melville H (1969) Redburn: his first voyage (1849). H Hayford, M Sealts, GT Tanselle (eds). Evanston and Chicago: Northwestern University Press and the Newberry Library.

Melville H (1970) Mardi (and a Voyage Thither) (1849). Hayford H, Sealts M, Tanselle GT (eds). Evanston and Chicago: Northwestern University Press and the Newberry Library.

Melville H (1988) Moby Dick, or The Whale. Hayford H, Sealts M, Tanselle GT (eds). Evanston and Chicago: Northwestern University Press and the Newberry Library.

Migliore S (1997) Mal'uocchiu: ambiguity, evil eye, and the language of distress. Toronto: University of Toronto Press.

Nicholson M (1999) Male envy: the logic of malice in literature and culture. Washington DC: Lexington Books.

Sealts M (1988) Melville's reading: revised and enlarged edition. Columbia: University of South Carolina Press.

Siebers T (1983) The mirror of Medusa. Berkeley: University of California Press.

Spooner B (1976). The evil eye in the Middle East. In The Evil Eye, C Maloney (ed), 7684. New York: Columbia University Press.

Stein H (1976) Envy and the evil eye: an essay in the psychological ontogeny of belief and ritual. In The Evil Eye, C Maloney (ed), 193-222. New York: Columbia University Press.

Thompson S (1966) Motif-index of folk literature, revised and enlarged edition. Bloomington: Indiana University Press.

Van Gennep A (1992) The research topic: or, folklore without end. In The Evil Eye: A Casebook, A Dundes (ed), 3-8. Madison: University of Wisconsin Press.

Wright N (1949) Melville's use of the Bible. Durham: Duke University Press. 
